\title{
Nitrogen Removal by Co-Immobilized Anammox and Ammonia-Oxidizing Bacteria in Wastewater Treatment
}

\author{
Igor Dolejš ${ }^{1}$, Radek Stloukal ${ }^{2}$, Michal Rosenberg ${ }^{1}$ and Martin Rebroš ${ }^{1, *}$ \\ 1 Institute of Biotechnology, Faculty of Chemical and Food Technology, Slovak University of Technology in \\ Bratislava, Radlinského 9, 81237 Bratislava, Slovakia; igor.dolejs@gmail.com (I.D.); \\ michal.rosenberg@stuba.sk (M.R.) \\ 2 LentiKat’s a.s., Pod Vinicí 83, 47127 Stráž pod Ralskem, Czech Republic; radek.stloukal@seznam.cz \\ * Correspondence: martin.rebros@stuba.sk; Tel.: +421-2-59-325-480
}

Received: 4 May 2019; Accepted: 7 June 2019; Published: 12 June 2019

\begin{abstract}
In wastewater treatment, an alternative to the widely used aerobic nitrification with subsequent anoxic denitrification method is the combination of nitration and anammox (AMX) in one system. This study focuses on the co-immobilization of AMX and ammonia-oxidizing bacteria into a polyvinyl alcohol (PVA) hydrogel, and its effective use in nitrogen removal (NR). The NR process was performed in nine consecutive, repeated batches. By optimizing the conditions of the biotransformations, there was equal utilization of nitrogen in both sources, $\mathrm{N}-\mathrm{NH}_{4}{ }^{+}$and $\mathrm{N}^{-\mathrm{NO}_{2}}{ }^{-}$, at $100 \% \mathrm{NR}$ during the sixth repetition. A significant increase in the immobilized co-culture activity was also detected per cycle. The maximum value of the NR rate was $3.46 \mathrm{mg} \mathrm{N}(\mathrm{L} \mathrm{h})^{-1}$, and $100 \% \mathrm{NR}$ efficiency was achieved with an initial concentration of $100.3 \mathrm{mg} \mathrm{N} \mathrm{L}^{-1}$ for N-NH${ }_{4}^{+}$and $60.1 \mathrm{mg} \mathrm{N} \mathrm{L}^{-1}$ for $\mathrm{N}-\mathrm{NO}_{2}{ }^{-}$, during the eighth batch biotransformation.
\end{abstract}

Keywords: anammox; immobilization; wastewater treatment; polyvinyl alcohol

\section{Introduction}

Organic nitrogen-containing compounds are among the most important pollutants of wastewater, and the removal of nitrogen is one of the crucial steps in wastewater treatment. These compounds represent a main factor in eutrophication, and they have an effect on the oxygen content of receiving waters as well as the toxicity to aquatic organisms and human beings [1,2]. For decades, a removal process based on aerobic nitrification with subsequent anoxic denitrification was used for the removal of such nitrogen-based compounds. The discovery of anaerobic oxidation of ammonium (anammox; AMX), with essential advantages of high nitrogen removal rate (NRR), environmental friendliness, low operational costs and low occupied areas, has been recognized as an attractive alternative for the treatment of nitrogen-rich wastewater streams [3-5]. The AMX process operates by oxidizing ammonia to nitrogen gas with nitrite as an electron acceptor under anoxic conditions. Meanwhile, the growth of AMX bacteria is supported by carbon dioxide fixation (Equation (1)), which is an advantage for the treatment of highly nitrogen-loaded wastewaters containing low biodegradable organic carbons [6-8].

$$
\mathrm{NH}_{4}{ }^{+}+1.3 \mathrm{NO}_{2}{ }^{-}+0.066 \mathrm{HCO}_{3}{ }^{-}+0.13 \mathrm{H}^{+} \rightarrow 1.02 \mathrm{~N}_{2}+0.26 \mathrm{NO}_{3}{ }^{-}+0.066 \mathrm{CH}_{2} \mathrm{O}_{2.5} \mathrm{~N}_{0.15}+2.03 \mathrm{H}_{2} \mathrm{O}
$$

As nitrite is needed for the AMX process at a molar ratio of 1:1.32 with ammonium [9], part of the ammonium in wastewater must be oxidized to nitrite with a pre-treatment system, such as the nitrosation process, realized by ammonia oxidizing bacteria (AOB), as shown in Equation (2) $[6,7,10]$. 


$$
2 \mathrm{NH}_{4}^{+}+3 \mathrm{O}_{2} \rightarrow 2 \mathrm{NO}_{2}^{-}+2 \mathrm{H}_{2} \mathrm{O}+4 \mathrm{H}^{+}
$$

Nevertheless, compared to conventional nitrification and denitrification, AMX consumes $100 \%$ less organic carbon and saves $90 \%$ of the operational costs associated with sludge disposal [11]. An alternative pre-treatment system for wastewater is the combination of nitrosation and AMX in one system. So far, it has mainly been applied for wastewaters with high concentrations of ammonia and low concentrations of biodegradable organic substances [12]. Functional AMX bacteria are very sensitive and are easily inhibited by many factors, such as low temperature (optimal range is $20-43^{\circ} \mathrm{C}$ ), extreme $\mathrm{pH}$ value (optimum $\mathrm{pH}$ 6.5-8.8), high salinity as well as the presence of organic matter, phosphates, sulfides and other inhibitors $[4,7]$.

For this reason, immobilization of microbial cells has received increasing interest in wastewater treatment in order to minimize the risk of biomass wash-out from the reactors and to provide a stabilized treatment [13]. The repeated use of immobilized biomass could handle the long start-up of AMX bacteria because of the very slow growth rate $\left(0.072 /\right.$ day at $\left.32^{\circ} \mathrm{C}\right)$ and low yield coefficient $(0.13 \mathrm{~g}$ dry weight $/ \mathrm{g}$ $\mathrm{NH}_{4}-\mathrm{N}$ oxidized) [11]. Immobilization of AMX bacteria through the entrapment method has been reported in several previous papers, using polyethylene glycol gel carriers [14,15] and polyvinyl alcohol (PVA) cryogel, prepared by physical cross-linking through the freezing/thawing method [13].

The aim of this research was to evaluate the effectiveness of co-immobilization of AMX bacteria and AOB by the entrapment method, immobilizing both bacteria into a PVA hydrogel, and its application in nitrogen removal (NR) during the water treatment process, using a real medium. The key issue in this application, however, is the harmonization of activities of both cultures. Therefore, we have focused on different process aspects to achieve this in co-immobilized form. Compared to other gel systems, immobilization using this method offers several advantages, such as a low matrix cost, inexpensive and simple gel preparation, uncomplicated separation from the reaction mixture and low diffusion limits. In addition, this matrix has excellent mechanical stability and is almost non-degradable [16].

\section{Results and Discussion}

The NR process using immobilized microbial co-cultures of AMX bacteria and AOB occurred in repeated batch-mode biotransformations. This experimental setup was made mainly because of the separate influences on each batch process (such as $\mathrm{pH}$ maintenance, nutrient limitation) which were evaluated after each separate batch. Another inspiration was to reach high NR efficiency. There were nine successive repetitions realized, as illustrated in Figure 1. The operational parameters were improved throughout the entire process and resulted in an increase of the nitrogen removal rate (NRR) and achieved a $100 \%$-successful transformation of substrate nitrogen compounds contained in the medium.

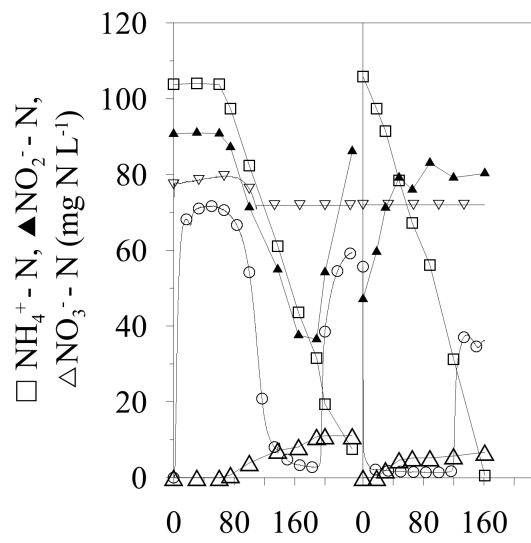

1.
2.

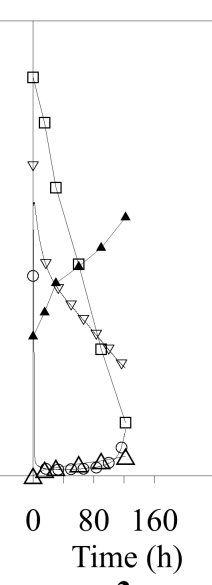

3.

Batch No
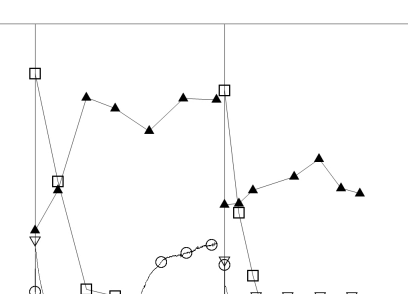

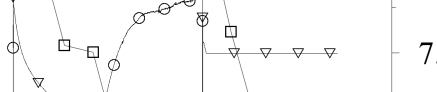

$\nabla \rightarrow-\nabla-6.0$

0 $\Delta \Delta \Delta \Delta \Delta \triangle \Delta \Delta \Delta \Delta \Delta \Delta \quad 5.0$

$\begin{array}{llllll}0 & 80 & 160 & 0 & 80 & 160\end{array}$

4.

5.

Figure 1. Cont. 


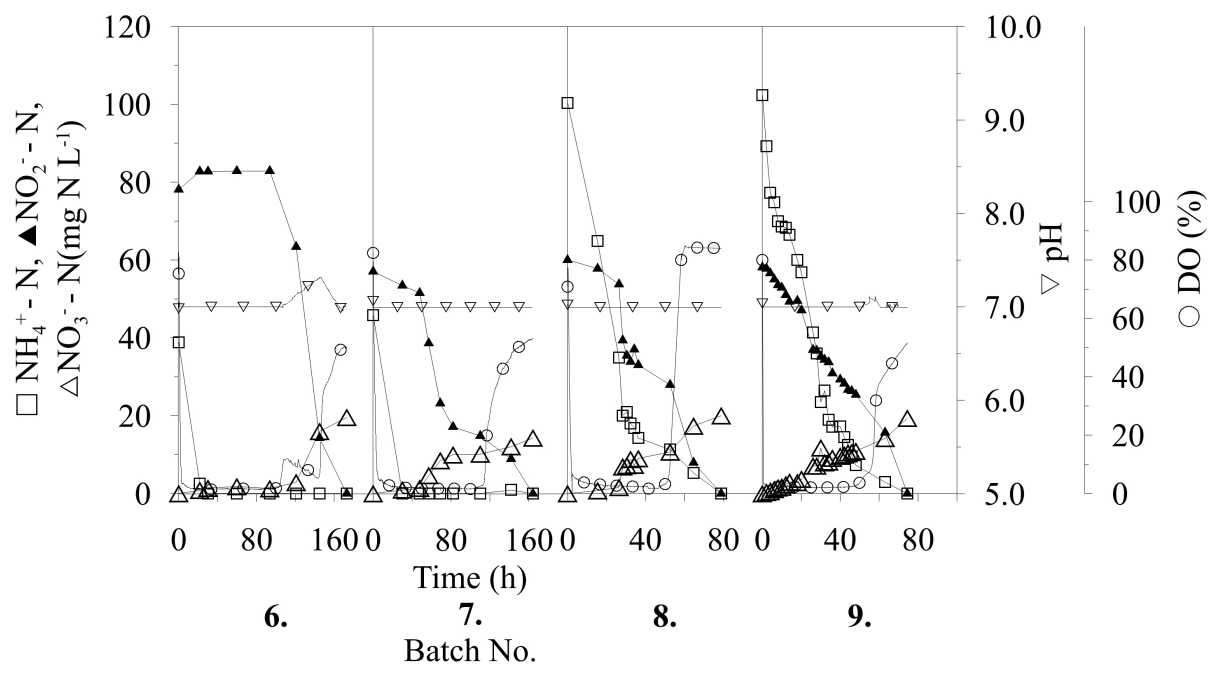

Figure 1. Repeated batch biotransformations with immobilized co-culture of anammox (AMX) bacteria and ammonia oxidizing bacteria AOB.

Figure 1 illustrates the process of each cycle of repeated biotransformation, and, as shown, low activity of the immobilized cells was observed during the first $60 \mathrm{~h}$ of the first biotransformation. This was most likely caused by the highly stressful aerobic conditions of the immobilization process to which the biomass was exposed for a short time beforehand. After this time, the oxygen started to decrease in the medium, as observed by a decrease in the dissolved oxygen (DO) content to $10 \%$, presumably caused by production of nitrogen gas (a final compound of nitrogen conversion). The higher activity of the immobilized bacteria also presented simultaneous utilization of $\mathrm{N}-\mathrm{NH}_{4}{ }^{+}$and $\mathrm{N}-\mathrm{NO}_{2}{ }^{-}$, probably caused by the suppression of the metabolic activity of one or more representatives of the immobilized AMX consortium also presented by formation of ions $\mathrm{N}-\mathrm{NO}_{3}{ }^{-}$. Utilization of $\mathrm{N}-\mathrm{NO}_{2}{ }^{-}$slowed around the middle of the first repeated batch and, instead of decreasing, it started to increase, according to the fermentation time. An increase of $\mathrm{N}_{-} \mathrm{NO}_{2}{ }^{-}$concentration and continuous utilization of $\mathrm{N}^{-} \mathrm{NH}_{4}{ }^{+}$was more likely caused by the activity of $\mathrm{AOB}$, which became dominant in the co-immobilized culture. As reported [17], AOB forms a thick layer around anammox cells which, after AOB domination, may eliminate the substrate (ammonia) access to AMX consortium (Equations $(1,2)$ ). During this first batch biotransformation, $52 \%$ of the total nitrogen was removed from compounds. The NRR, calculated from 0 to $30 \mathrm{~h}$ for each batch, was constant at $0 \mathrm{mg} \mathrm{N}(\mathrm{L} \mathrm{h})^{-1}$ because of the long lag phase. After $256 \mathrm{~h}$ of the first biotransformation, the whole volume of the medium was separated through a sieve, subsequently fed with fresh medium and the next biotransformation was started.

As shown in Figure 1, the trend of nitrite production continued during the second batch, this time from the beginning of biotransformation. On the other hand, the low value of DO provides a prerequisite, indicating that the AMX consortium was only temporarily suppressed and not inhibited, presented by production of gaseous nitrogen and formation of ions $\mathrm{N}-\mathrm{NO}_{3}{ }^{-}$. The $\mathrm{NR}$ and NRRs achieved were similar to the results of the first batch, owing to increasing nitrite production.

\subsection{Influence of $\mathrm{pH}$ on the Process}

After the second biotransformation, the operation conditions were changed, which were intended to provide an advantage to the AMX part of the immobilized biomass. The first parameter modified was the $\mathrm{pH}$ of the process, with reference to published data of $\mathrm{pH}$ optimum of $6.5-8.8$ for AMX cultivation [7]. According to this fact, a spontaneous decrease of the $\mathrm{pH}$ value during the process was performed instead of a $\mathrm{pH}$ stat at 8.0, as previously used. Following this change, a decrease in $\mathrm{pH}$ from 8.0 to 6.18 (after $122 \mathrm{~h}$ ) and from $\mathrm{pH} 7.6$ to 6.0 (after $110 \mathrm{~h}$ ) was observed in the third and fourth biotransformations, respectively. Although there was no change in nitrite production during these processes, an increase in the utilization of $\mathrm{N}_{-} \mathrm{NH}_{4}{ }^{+}$was observed, according to time of 
biotransformation. For the third batch, an NRR of $0.50 \mathrm{mg} \mathrm{N}(\mathrm{L} \mathrm{h})^{-1}$ and $42 \% \mathrm{NR}$ was achieved, whereas for the fourth batch, the NRR was $0.59 \mathrm{mg} \mathrm{N}(\mathrm{L} \mathrm{h})^{-1}$ and $43 \% \mathrm{NR}$ was achieved. Compared with previously achieved values, and as illustrated in Figure 2, there is a clear increase in the NRR despite a decrease in NR, which represents the activity of the whole process. During the fifth biotransformation, the $\mathrm{pH}$ stat was reset to $\mathrm{pH} 7.0$ and, as shown in Figure 1, the increase in $\mathrm{N}-\mathrm{NO}_{2}{ }^{-}$concentration was significantly reduced for only $4.4 \mathrm{mg} \mathrm{N} \mathrm{L}^{-1}$ in the period $0-120 \mathrm{~h}$, as compared with previous (second to fourth) conversions with an increase of about $31.9 \pm 0.3 \mathrm{mg} \mathrm{N} \mathrm{L}^{-1}$.
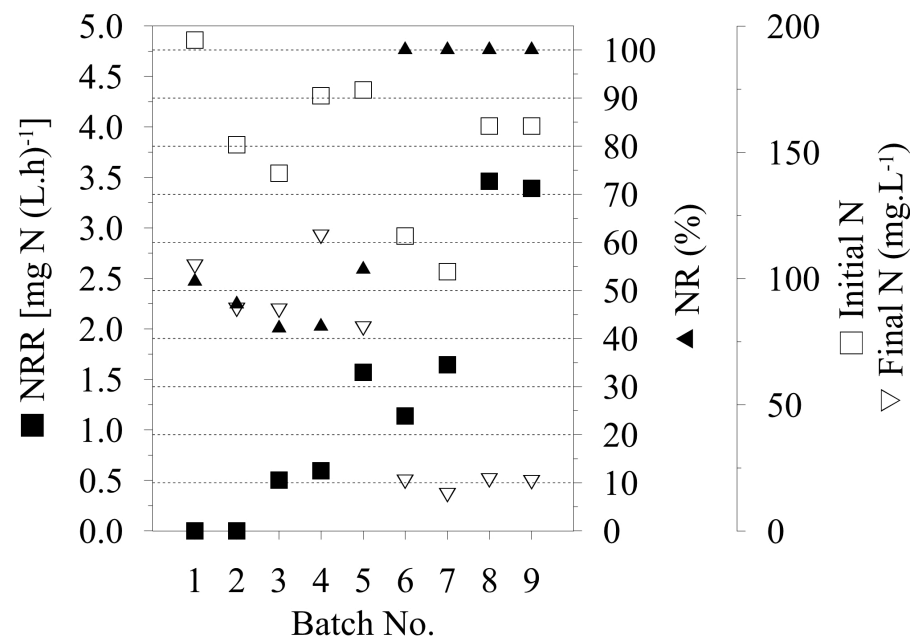

Figure 2. Nitrogen removal rate (NRR) calculated for the period 0-30 h of each biotransformation cycle, nitrogen removal (NR) calculated for entire duration of biotransformation and total, initial and final nitrogen.

\subsection{AMX Bacteria Stimulation}

Compared to AOB, AMX bacteria has extremely slow biomass growth (doubling time between 2.1 and 3.9 days) [18]. Therefore, AMX biomass suffers to be overgrown by AOB in the previous repeated batches. To increase the AMX bacterium, the nutritional limitation (decrease of $\mathrm{N}^{-} \mathrm{NH}_{4}{ }^{+}$) of $\mathrm{AOB}$ was applied. In the following two biotransformations (sixth and seventh), the initial concentration of $\mathrm{N}-\mathrm{NH}_{4}{ }^{+}$was decreased two-fold in an attempt to stimulate AMX bacteria at the expense of the other co-immobilized bacteria. At first, total utilization of $\mathrm{N}-\mathrm{NH}_{4}{ }^{+}$was observed after $25 \mathrm{~h}$ of biotransformation (sixth batch). Then, after $100 \mathrm{~h}$, relatively high-speed utilization of $\mathrm{N}^{-\mathrm{NO}_{2}{ }^{-} \text {was }}$ observed, which decreased a concentration to $14.2 \mathrm{mg} \mathrm{N} \mathrm{L}^{-1}$ from $78.1 \mathrm{mg} \mathrm{N} \mathrm{L}^{-1}$ after $45 \mathrm{~h}$ (145th hour of biotransformation) by simultaneous formation of $19.52 \mathrm{mg} \mathrm{N} \mathrm{L}^{-1}\left(\mathrm{~N}-\mathrm{NO}_{3}{ }^{-}\right)$. The $\mathrm{N}-\mathrm{NO}_{3}{ }^{-}$ confirms the trend of AMX bacteria activation at the end of this batch. Finally, a total NR of $100 \%$ was observed (calculated on initial N-NH${ }_{4}{ }^{+}, \mathrm{N}-\mathrm{NO}_{2}{ }^{-}$) despite it being at the expense of an NRR decrease (Figure 2). During the seventh batch, synchronic utilization of both sources of nitrogen was observed from the beginning of the biotransformation. An NRR of $1.65 \mathrm{mg} \mathrm{N}(\mathrm{L} \mathrm{h})^{-1}$ was achieved, as calculated for the period of $0-30 \mathrm{~h}$, which is similar to the value of $1.57 \mathrm{mg} \mathrm{N}(\mathrm{L} \mathrm{h})^{-1}$ that was achieved in the fifth biotransformation, with the difference of $100 \%$ NR observed during seventh biotransformation (Figure 2). This confirmed the correctness of the chosen procedure in the sixth batch, with a decrease in the initial concentrations of $\mathrm{N}-\mathrm{NH}_{4}{ }^{+}$for AMX stimulation, and led to improved total nitrogen utilization and activity of the whole process with immobilized co-cultures. Furthermore, the effectivity of the process was also apparent from the initial and final content of total $\mathrm{N}$ between sixth and ninth batch (Figure 2). The difference between initial and final $\mathrm{N}$ content confirms the efficient process strategy in batch numbers eight and nine. 


\subsection{Harmonised Co-Culture Experiments}

During the eighth and ninth biotransformations, the initial concentration of $\mathrm{N}-\mathrm{NH}_{4}{ }^{+}$was increased

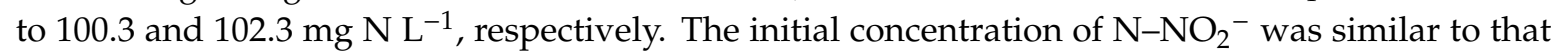
used in previous repeated batch biotransformations at 60.1 and $58.1 \mathrm{mg} \mathrm{N} \mathrm{L}^{-1}$ for the eighth and ninth biotransformations, respectively. As shown in Figure 1, simultaneous utilization of $\mathrm{N}^{-\mathrm{NH}_{4}}{ }^{+}$ and $\mathrm{N}-\mathrm{NO}_{2}{ }^{-}$was observed from the beginning of both biotransformations. For both, $100 \% \mathrm{NR}$ was observed after $75 \mathrm{~h}$ (ninth batch) and $78 \mathrm{~h}$ (eighth batch).

During the eighth batch, the higher NRR of $3.46 \mathrm{mg} \mathrm{N}(\mathrm{L} \mathrm{h})^{-1}$ was achieved in the $0-30 \mathrm{~h}$ period (Figure 2), and a similar rate of $3.39 \mathrm{mg} \mathrm{N}(\mathrm{L} \mathrm{h})^{-1}$ was observed during the ninth biotransformation. Although the highest achieved value of the NRR was 2.8 times lower than published data on a similar topic [9.8 $\mathrm{mg} \mathrm{N}(\mathrm{L} \mathrm{h})^{-1}$ ], the observed NR efficiency in this study achieved 100\% compared to reported $85 \%$ to $95 \%$ by Jenni et al. [12]. However, in this study, only small amount of immobilized biomass was applied ( $10 \% \mathrm{w} / \mathrm{v}$ particles load; in total $0,6 \mathrm{~g}$ of co-immobilized biomass per $\mathrm{L}$ of treated waste water). As reported recently [19], further process intensification is possible by the increase of immobilized biomass up to $20 \mathrm{~g} \mathrm{~L}^{-1}$ of dry cell weight biomass, with no change in immobilized particles structure. Interestingly, this overload of biomass results in linear increase of the specific immobilized biomass activity as well. In the case of AMX and $\mathrm{AOB}$ co-immobilization, this may result in a more than 30-fold increase of initial specific activity. The further increase in the NRR can be also obtained by increase of the total amount of used immobilized particles $(10 \% \mathrm{w} / \mathrm{v}$ in these experiments) to maximum of $30 \%$ $(\mathrm{w} / \mathrm{v})$ [20], which results in an increase of total activity of the biotransformation system. Therefore, we believe that this co-immobilized system has a potential for further applications in waste water treatment processes.

\section{Materials and Methods}

\subsection{Medium}

The cultivation medium $(0.8 \mathrm{~L})$ was composed of real wastewater (received as a product from machine-sludge thickening) obtained from Central WWTP Vrakuňa, Bratislava, Slovakia, and aged tap water (left to sit for $24 \mathrm{~h}$ for chlorine evaporation) in a volumetric ratio of 3:5. The characteristics of the wastewater were a $\mathrm{pH}$ value of 7.4, a chemical oxygen demand of $370 \mathrm{mg} \mathrm{L}^{-1}$, a five-day biochemical oxygen demand of $138 \mathrm{mg} \mathrm{L}^{-1}$, a suspended solids content of $678 \mathrm{mg} \mathrm{L}^{-1}$, an ammonium nitrogen $\left(\mathrm{N}-\mathrm{NH}_{4}{ }^{+}\right)$concentration of $275 \mathrm{mg} \mathrm{L}^{-1}$ and a total nitrogen content of $673 \mathrm{mg} \mathrm{L}^{-1}$. The nitrite nitrogen $\left(\mathrm{N}-\mathrm{NO}_{2}{ }^{-}\right)$and nitrate nitrogen $\left(\mathrm{N}-\mathrm{NO}_{3}{ }^{-}\right)$contents were not detectable. To increase the $\mathrm{N}-\mathrm{NO}_{2}{ }^{-}$ concentration, $0.2 \mathrm{~g}$ of $\mathrm{NaNO}_{2}$ (Mikrochem, Slovakia) was added into the cultivation medium. The final concentration of $\mathrm{N}-\mathrm{NH}_{4}{ }^{+}$in the cultivation medium was $103 \pm 2 \mathrm{mg} \mathrm{N} \mathrm{L}^{-1}$, except for the sixth and seventh conversions, which started with concentrations of 38.8 and $45.8 \mathrm{mg} \mathrm{N} \mathrm{L}^{-1}$, respectively. The final concentration of $\mathrm{N}_{-} \mathrm{NO}_{2}{ }^{-}$was $62 \pm 15 \mathrm{mg} \mathrm{L}^{-1}$. The medium was purged with $\mathrm{N}_{2}$ for $15 \mathrm{~min}$ to remove the dissolved $\mathrm{O}_{2}$, but this was only performed before the first biotransformation.

\subsection{Biomass Immobilisation}

Biomass used for immobilization was received from the Institute of Chemical Technology (ICT), Prague, Czech Republic, propagated in lab-scale conditions by use of real wastewater obtained from WWTP Prague. Using fluorescence in situ hybridization (FISH) by ICT, the composition of the received consortium of bacteria was characterized as $20 \%$ to $30 \%$ AMX bacteria and $70 \%$ to $80 \%$ of AOB. The biomass $(1 \pm 0.2 \mathrm{~g}$ wet weight) was softly suspended in $10 \mathrm{~mL}$ of aged tap water and mixed with $190 \mathrm{~mL}$ PVA hydrogel, prepared by using of PVA ( $20 \mathrm{~g})$ and polyethylene glycol (12 g), which were melted in deionized water $(158 \mathrm{~mL})$ at $90^{\circ} \mathrm{C}$ until clarification and then cooled to $30{ }^{\circ} \mathrm{C}$. Lens-shaped gel particles with entrapped biomass were prepared by passing the gel mixture through thin nozzles to a hard surface, followed by subsequent drying in an airflow cabinet for $55 \mathrm{~min}$. Particles were dried down to $30 \%$ of their initial mass and swollen in a stabilizing solution of $0.1 \mathrm{M}$ sodium sulfate for 
30-45 $\mathrm{min}$. Then, the particles were separated through a sieve and washed from the stabilizing solution by deionized water. Using the mentioned LentiKats ${ }^{\circledR}$ method of immobilization, a final amount of $85 \mathrm{~g}$ of immobilized biomass was acquired.

\subsection{Repeated Batch Biotransformation}

Batch biotransformations with immobilized biomass were performed in a $1.3 \mathrm{~L} \mathrm{BioFlo}{ }^{\circledR} 115$ fermenter (New Brunswick, USA) in which $0.8 \mathrm{~L}$ of the cultivation medium was inoculated with $85 \mathrm{~g}$ of LentiKats ${ }^{\circledR}$. Each biotransformation was carried out at either $\mathrm{pH} 8.0$ (first and second batch) or pH 7.0 (fifth to ninth batch) by automatic addition of $2 \mathrm{M} \mathrm{NaOH}$ at $30{ }^{\circ} \mathrm{C}$ with $250 \mathrm{rpm}$ stirring. Repeated batch-mode biotransformations occurred when the residual concentrations of $\mathrm{N}^{-\mathrm{NH}_{4}}{ }^{+}$and $\mathrm{N}-\mathrm{NO}_{2}{ }^{-}$were reduced to almost $0 \mathrm{mg} \mathrm{N} \mathrm{L}^{-1}$ or did not change in the long term. This situation was solved by separating the entire volume of the production medium through a sieve to avoid washing out the LentiKats ${ }^{\circledR}$ with the immobilized biomass. The fermenter was subsequently fed with a fresh cultivation medium. Experiments were duplicated, and datapoints represent mean value of the process (SD was lower than $5 \%$ ).

\subsection{Analytical Assays}

The concentrations of $\mathrm{N}-\mathrm{NH}_{4}{ }^{+}, \mathrm{N}-\mathrm{NO}_{2}{ }^{-}$and $\mathrm{N}-\mathrm{NO}_{3}{ }^{-}$were determined by methods described in the Standard Methods for the Examination of Water and Wastewater [21], using a BioSpectometer ${ }^{\circledR}$ (Eppendorf, Germany). Dissolved oxygen (DO) was measured using a polarographic DO probe, and the $\mathrm{pH}$ value of the medium was measured using a $\mathrm{pH}$ probe, both of which are components of the BioFlo ${ }^{\circledR} 115$ fermenter. NR and NRR were calculated to the depletion of primary sources of nitrogen: $\mathrm{N}-\mathrm{NH}_{4}{ }^{+}$and $\mathrm{N}-\mathrm{NO}_{2}{ }^{-}$.

\section{Conclusions}

The presented results emphasize that the use of a small amount of immobilized biomass ( $0.6 \mathrm{~g}$ of immobilized wet weight per $\mathrm{L}$ of treated waste water) can be advantageous in large-scale applications, owing to the low biomass-production rate of AMX bacteria and AOB. The decrease of $\mathrm{N}^{-\mathrm{NH}_{4}}{ }^{+}$leads to starvation of $\mathrm{AOB}$, which stimulates the AMX bacteria and significantly improves the total nitrogen utilization and activity of co-immobilized cultures. This starvation technique is a useful trick for co-culture activities harmonization, which resulted in high overall nitrogen removal activity. At optimal conditions $\mathrm{pH}=7$ and initial concentrations $\mathrm{N}-\mathrm{NH}_{4}{ }^{+} 100.3 \mathrm{mg} \mathrm{N} \mathrm{L}^{-1}$ and $\mathrm{N}_{-} \mathrm{NO}_{2}{ }^{-} 60.1 \mathrm{mg} \mathrm{L}^{-1}$, at $30^{\circ} \mathrm{C}$ with gentle (250 rpm) batch bioreactor stirring, an immobilized consortium was able to remove $160.4 \mathrm{mg} \mathrm{N} \mathrm{L}^{-1}$ of initial nitrogen sources from wastewater within $80 \mathrm{~h}$ with $\mathrm{NR}$ rate $3.46 \mathrm{mg} \mathrm{N}(\mathrm{L} \mathrm{h})^{-1}$. This is the first report on the immobilization of AMX bacteria and AOB into a PVA hydrogel to indicate the methods, $\mathrm{pH}$ stat and substrate limitation that stimulate the co-immobilized bacteria activity in biotransformations. This co-culture improvement strategy might be beneficial for further co-immobilization studies and applications.

Author Contributions: I.D. investigation, writing-original draft preparation; R.S. methodology; M.R. (Michal Rosenberg) conceptualization, funding acquisition; M.R. (Martin Rebroš) writing-review and editing, methodology, funding acquisition.

Funding: This work was supported by the Ministry of Industry and Trade of the Czech Republic, programme TIP, grant no. FR-TI4/254 and was cofounded by the Slovak Research and Development Agency under contract no. APVV-16-0314. This publication is the result of the project implementation: Comenius University in Bratislava Science Park supported by the Research and Development Operational Programme funded by the ERDF. Grant number: ITMS 26240220086.

Conflicts of Interest: The authors declare no conflict of interest. 


\section{References}

1. Ni, B.-J.; Smets, B.F.; Yuan, Z.; Pellicer-Nàcher, C. Model-based evaluation of the role of Anammox on nitric oxide and nitrous oxide productions in membrane aerated biofilm reactor. J. Membr. Sci. 2013, 446, 332-340. [CrossRef]

2. Paredes, D.; Kuschk, P.; Mbwette, T.S.A.; Stange, F.; Müller, R.A.; Köser, H. New aspects of microbial nitrogen transformations in the context of wastewater treatment-A review. Eng. Life Sci. 2007, 7, 13-25. [CrossRef]

3. Bi, Z.; Qiao, S.; Zhou, J.; Tang, X.; Cheng, Y. Inhibition and recovery of Anammox biomass subjected to short-term exposure of $\mathrm{Cd}, \mathrm{Ag}, \mathrm{Hg}$ and Pb. Chem. Eng. J. 2014, 244, 89-96. [CrossRef]

4. Liu, S.; Zhang, Z.; Ni, J. Effects of $\mathrm{Ca}^{2+}$ on activity restoration of the damaged anammox consortium. Bioresour. Technol. 2013, 143, 315-321. [CrossRef] [PubMed]

5. Ma, B.; Peng, Y.; Zhang, S.; Wang, J.; Gan, Y.; Chang, J.; Wang, S.; Wang, S.; Zhu, G. Performance of anammox UASB reactor treating low strength wastewater under moderate and low temperatures. Bioresour. Technol. 2013, 129, 606-611. [CrossRef] [PubMed]

6. Gao, F.; Zhang, H.; Yang, F.; Qiang, H.; Li, H.; Zhang, R. Study of an innovative anaerobic (A)/oxic $(\mathrm{O})$ /anaerobic (A) bioreactor based on denitrification-anammox technology treating low $\mathrm{C} / \mathrm{N}$ municipal sewage. Chem. Eng. J. 2013, 232, 65-73. [CrossRef]

7. Magrí, A.; Béline, F.; Dabert, P. Feasibility and interest of the anammox process as treatment alternative for anaerobic digester supernatants in manure processing-An overview. J. Environ. Manag. 2013, 131, 170-184. [CrossRef] [PubMed]

8. Huang, X.-W.; Wei, Q.-Y.; Urata, K.; Tomoshige, Y.; Zhang, X.-H.; Kawagoshi, Y. Kinetic study on nitrogen removal performance in marine anammox bacterial culture. J. Biosci. Bioeng. 2014, 117, 285-291. [CrossRef] [PubMed]

9. Jin, R.-C.; Xing, B.-S.; Yu, J.-J.; Qin, T.-Y.; Chen, S.-X. The importance of the substrate ratio in the operation of the Anammox process in upflow biofilter. Ecol. Eng. 2013, 53, 130-137. [CrossRef]

10. Isaka, K.; Kimura, Y.; Yamamoto, T.; Osaka, T.; Tsuneda, S. Complete autotrophic denitrification in a single reactor using nitritation and anammox gel carriers. Bioresour. Technol. 2013, 147, 96-101. [CrossRef] [PubMed]

11. Anjali, G.; Sabumon, P.C. Unprecedented development of anammox in presence of organic carbon using seed biomass from a tannery Common Effluent Treatment Plant (CETP). Bioresour. Technol. 2017, 153, 30-38. [CrossRef] [PubMed]

12. Jenni, S.; Vlaeminck, S.E.; Morgenroth, E.; Udert, K.M. Successful application of nitritation/anammox to wastewater with elevated organic carbon to ammonia ratios. Water Res. 2014, 49, 316-326. [CrossRef] [PubMed]

13. Magrí, A.; Vanotti, M.B.; Szögi, A.A. Anammox sludge immobilized in polyvinyl alcohol (PVA) cryogel carriers. Bioresour. Technol. 2012, 114, 231-240. [CrossRef] [PubMed]

14. Furukawa, K.; Inatomi, Y.; Qiao, S.; Quan, L.; Yamamoto, T.; Isaka, K.; Sumino, T. Innovative treatment system for digester liquor using anammox process. Bioresour. Technol. 2009, 100, 5437-5443. [CrossRef] [PubMed]

15. Isaka, K.; Date, Y.; Sumino, T.; Tsuneda, S. Ammonium removal performance of anaerobic ammoniumoxidizing bacteria immobilized in polyethylene glycol gel carrier. Appl. Microbiol. Biotechnol. 2007, 76, 1457-1465. [CrossRef] [PubMed]

16. Rebroš, M.; Rosenberg, M.; Stloukal, R.; Krištofíková, L. High efficiency ethanol fermentation by entrapment of Zymomonas mobilis into LentiKatsR. Lett. Appl. Microbiol. 2005, 41, 412-416. [CrossRef] [PubMed]

17. Qiao, S.; Tian, T.; Duan, X.; Zhou, J.; Cheng, J. Novel single-stage autotrophic nitrogen removal via co-immobilizing partial nitrifying and anammox biomass. Chem. Eng. J. 2013, 230, 19-26. [CrossRef]

18. Zhang, L.; Narita, Y.; Gao, L.; Ali, M.; Oshiki, M.; Okabe, S. Maximum specific growth rate of anammox bacteria revisited. Water Res. 2017, 116, 296-303. [CrossRef] [PubMed]

19. Zajkoska, P.; Rosenberg, M.; Heath, R.; Malone, K.J.; Stloukal, R.; Turner, N.J.; Rebros, M. Immobilised whole-cell recombinant monoamine oxidase biocatalysis. Appl. Microbio. Biotechnol. 2015, 99, 1229-1236. [CrossRef] [PubMed] 
20. Stloukal, R.; Rosenberg, M.; Rebros, M. Method for industrial production of biocatalysts in the form of enzymes or microorganisms immobilized in polyvinyl alcohol gel, their use and devices for their production. WO/2007/104268, 20 December 2007.

21. APHA, AWWA, WEF. Standard Methods for the Examination of Water and Wastewater, 21st ed.; American Public Health Association/American Water Works Association/Water Environment Federation: Washington DC, WA, USA, 1998.

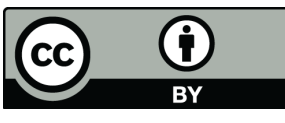

(C) 2019 by the authors. Licensee MDPI, Basel, Switzerland. This article is an open access article distributed under the terms and conditions of the Creative Commons Attribution (CC BY) license (http://creativecommons.org/licenses/by/4.0/). 